\title{
Relationship between Government Budget Deficits and Inflation in the Iran's Economy
}

\author{
${ }^{1}$ Safdari Mehdi, ${ }^{2}$ Motiee Reza* \\ ${ }_{1}^{1}$ Department of Economics, University of Qom, Iran \\ ${ }^{2}$ Department of Economics, Babol Branch, Islamic Azad University, Babol, Iran \\ *rm.search2011@gmail.com
}

\begin{abstract}
Government in the economy of a country is responsible for various duties and to do these tasks uses the budget and fiscal policy as a planning and control tools. Because the different goals of economic balance in macro level such as fixing prices and unemployment inhibit any economic program is the priority, so can the government is using funds that involve income and expenses of the government to direct economic in reaching their goals in macro level. In developing countries lacked the private sector are strong, the role of government and its dimensions are larger tasks. The basic aim of the paper is to analyze the Relationship between government budget deficits and inflation in the Iran's economy. According to the positive and significant coefficient of government budget deficit, if budget deficit change to one percent, the inflation rate will change to 1.82 percent.
\end{abstract}

Key words: Inflation, budget deficits, liquidity growth, Auto Regressive Distributed Lag (ARDL)

\section{Introduction}

Economic effects of government deficits depends on factors appearing, financing methods it and the country macroeconomic conditions. If the government budget is to reduce by consumer spending inflation may appear given that only total demand is increased the cause of this type of expenditure. But if the government budget deficits is due to run an active fiscal policy, in order to rid the economy from recession, increasing government spending and make their investments in the budget deficit acts as an expansionary fiscal policy and its economic effects in the long run will economy was directed towards employment. This type of budget deficits in developing countries today is considered as a policy tool. Overall, the supply of government deficit will be done three ways; borrowing from abroad, domestic borrowing (bonds release), and borrowing from the banking system. If the deficit be met through borrowing from the banking system, because it increases liquidity and consequent increase in aggregate demand will work with the poor economy such as inflation. If the deficit through domestic borrowing (bonds release) which means the government demand for credit is available in society, increase interest rates in the community and followed by reduced private sector investment.

It should be noted that if the central bank interest rates in order to take over part of government debt to convert to cash, thereby increasing the money supply and inflation rises. Finally, if the deficit be met through foreign borrowing may lead to current account deficit and sometimes led to foreign debt crisis. Overall economic situation is another factor that affects how the impact on the deficit. There is following question always that what are the consequences of budget deficits? How can inflation be controlled? Is there a relationship between budget deficits and inflation? In this connection, several theories have been presented about the relationship between budget deficits, money, inflation and policies related to them. If the economy is below full employment and the overflow level of liquidity and there is thus possible to increase employment and production, thus increasing the government deficit spending, particularly investment spending, cannot be inflamed. Moreover, the impact on inflation, budget deficits, inflation has an impact on the deficit. In this article, we are looking for the amount of this effect on the swelling budget deficit to within four of the last decade. For this important issue, spent the second part article examines the various theories about how to balance the budget and the influence on the swelling budget deficit, the next practical. In the third part is presented a statistical analysis of the trend rate of inflation and budget deficits of. At the end of stipulated order model is available for estimating and analyzing the results.

\section{Literature Review}

Due to the importance of the topic, several studies have been conducted in developing countries and industrial like Francis and Miller (1985) studied the relationship between government deficits, money growth and inflation. They used the three-variable auto correlation model and split the period (1947- 
1980) into three smaller periods. Comparison of the results for the three periods stated that inflation in these periods was the impact on the growth of monetary base; the government deficit also affected the growth of monetary base, which eventually led to inflation. Therefore, in general, study expressed an indirect causal relationship between variables. Protopapadakis and Siegel (1987) studied the relationship between money growth and inflation with government deficit for 10 industrialized countries in the period 1983-1952. Study first analyzed the theoretical model then the non-parametric and concluded that there was a significant relationship between debt growth and money growth during 32 years period. Aghevli and khan (1978) studied Government budget deficits and the inflationary process in developing countries. They have investigated a cause and effect relationship between money supply and prices for several countries. They have described the process of inflation in these countries by providing a dynamic model. They concluded that the time lags average for taxes is more than the time lags average for Government spending. Consequently, government spending increases faster than nominal incomes in inflationary conditions and provided additional spending can make to increase the money supply that comes with higher prices.

Barro (1974) presented a model with the budget issue as money growth and inflation, $\mathrm{DM}=\mathrm{f}$ (NN-1, FEDV, DM-1). In the model, DM is the money growth and $U$ is unemployment. In fact, the positive response of money growth in the unemployment rate is expressed in the opposite direction of monetary policy actions economy era. FEDV is changes in the logarithm real central government spending. If the government from printing money to use taxes in addition to minimizing the financial cost of government spending, government spending variable will have a positive impact on money growth. Jafarisamimi (1992) studied two-way communication between government budget deficits and inflation during the period (1971-1991) in the Iran's economy using Ordinary Least Square (OLS) method. Study concluded that there is a two-way communication between government budget deficits and inflation. Increase the budget deficit will raise inflation rate by monetary base and supply and rising inflation rate leads to the nominal government budget deficit. Alavirad (2006) studied budget deficits and inflationary process with the approach of VAR in Iran. Study estimated a model that included deficit variables, consumer price index, monetary base, the official exchange rate and net government debt to the central bank during 1963-1996. Study concluded that budget deficit has impact on inflation directly and most effective after the monetary base. Mousavi-Azad (1999) studied the relationship between government budget deficit, economic growth and inflation by Vector Auto Regressive (VAR) during 1963 - 1996. Study analyzed them using shock reaction function and analysis of variance. Results showed that policy can provide the deficit in the short term increase in production fields and leads to increased economic growth, but only leads to inflation in the long run it does not impact on economic growth.

\section{Evaluation of theories about the government budget balance}

In Public sector economics there are different theories on the fact that the government should maintain an annual balanced budget or not. These can be divided into the following three groups:

- The annual observance was quite balanced (classical theory)

- Lack of balance in government budgets

- Support of the budget balance, but not annually

The annual observance was quite balanced (classical theory): the fans of this theory believe, government is obliged to balance its annual budget is adhered to the revenue expenditure. Reasons supporting the groups are:

- As the budget balance is respected in the private sector good economy balance the annual budget such as private finance would be the appropriate thing.

- The state budget deficit will cause inflation and the budget imbalance makes the government fails to rein inflation.

- Force the government to observe the annual budget will prevent uncontrolled growth of public sector and government spending (especially wasteful spending).

- People of the political resistance to tax increases against the government for financial costs, so should not be allowed to be faced with budget deficits.

Imbalance in the budget: theory versus the annual budget, policy advocates a balanced budget, nondemanding tasks are the government's economic and believe, the most important duty of governments to 
create economic stability, through the budget and the economy is not anything to be noticed government budget balance or imbalance. In other words, there may need to imbalance in the budget and budget sometimes occurs randomly balanced budget. In summary, according to economic theory is Keynesian deficit by money in the hands of the people and businesses increases demand for goods and services in the community. So the economy is stimulated. On the surplus money pulled out of the economy and reduce aggregate demand for goods and services and thus limits the economy.

Support the balanced budget, but not annual basis: attention to the issue of balance in the annual budget, is just the political aspect. There are also continuing a long-term imbalances in the budget may be works of disadvantage. So fans of the third approach, which compared with the middle mode are the two previous theories believe in a government budget should be balanced around this business a few years of impairments resulting from the annual budget balance, as well aware there are problems of imbalance long and demand situation that could create a deficit by the recession period to compensate for the excess period of prosperity. So they are demanding the government budget balance periodically.

\section{Theoretical Foundations in the effect of budget deficit on inflation}

Effect on the swelling budget deficit, lot depends on how to finance it and transient or permanent deficit. Financing the deficit can be done through several methods. a) Change in taxes rate, $b$ ) get help from the banking system and increase the volume of money, $c$ ) Land Use reserves external, d) and borrowing from abroad by borrowing from the domestic bond release. There is always the question of whether the deficit has consequences and how inflation is controlled and whether the relationship between budget deficits and inflation can be found or not? Various theories are presented about the relationship between budget deficits, inflation and money and their related policies Including opinions Keynesian and supporters of the school monetary. Keynesian suggests a drastic reduction in government budget deficit for inflation but supporters of the school monetary called Milton Friedman lays emphasis on precise control on the money supply for this purpose. Therefore, theories and fans Keynesian school money be considered factors in determining prices, the economy.

In this connection, knowledge of the relationship between budget deficits, money and inflation in determining monetary and fiscal policies of the government has a great importance. Considering that money growth is one of the causes of inflation and there is serious budget deficit in Iran, it is necessary to review the impact of budget deficit on Money growth and inflation.

\section{Budget Deficits and Inflation in Iran's Economy}

In the years after 1988, the deficit in income levels the government hidden costs. In the years before 1989, the deficit in public companies as well as statistics would reflect the state budget deficit. But then the figures were not considered in the state budget deficit. As a result of the 1989 budget deficit than the government, is severely reduced GDP. After about four times, to increase oil prices in 1974, the Government part of their extra oil revenue before the deadline for settlement of foreign debts, put to use. But the rapid growth of government spending over the decade and increased 50 deficits, forced the government to be financed through deficit and foreign borrowing. In the years after the Islamic Revolution, despite contractionary fiscal policies, due to reduced oil revenues, the government deficit increased strongly, so that amount in 1988 reached 2111.7 billion IRR ${ }^{1}$. From 1989 onwards the government's efforts to reform the budget structure in 1991 to 3698.5 billion IRR in 2006 and reached 147431.15 billion IRR. Inflation in Iran, the decade in 1961 with a slow ascending trend began in the early decades of the 50th, but due to increased oil revenues and lack of proper use of petro-dollars increased by inflation. More quickly and after the revolution, war, exchange rates, devaluation of national currency, reduce production and eventually increase the demand by the people and lack of appropriate policy implementation, inflation rate, so far risen from 1\% in 1965 to its maximum i.e. $49 \%$ in reached 1995 and then has continued its upside remains nearly enough. Inflation in 2006 reached to $13 \%$.

\footnotetext{
${ }^{1}$ IRR is monetary unit in Iran. Based on ISO-4217 standard Iran's Rial is shown with the symbol IRR In global trading.
} 


\section{Methodology}

We can study effect of budget deficits on inflation in the following two conditions: an indirect effect of the deficit through money supply on inflation, the second direct effect on the swelling budget deficit, this study looks for a direct effect on the swelling budget deficit. Following the pattern has been observed.

$$
L n C P I 76_{t}=\alpha_{0}+\sum_{j=0}^{n 1} \alpha_{1 j} L n G D P R_{-j}+\sum_{j=0}^{n 2} \alpha_{2 j} L n M 2_{t-j}+\sum_{j=0}^{n 3} \alpha_{3 j} B D T_{t-j}+\delta^{\prime} D M_{t}+u_{t}
$$

The variables including:

Ln is the Logarithm sign

CPI76: consumer price index, constant prices 1997

Ratio of deficit to GDP over the market price and current price following:

$$
\frac{B D}{G D P}=B D T
$$

GDPR: GDP, market prices and constant prices, 1997

$\mathrm{M}_{2}$ : Size liquidity

DM: the Dummy variable includes: (D1994), policies exchange rate unification in 1994, and (D1978), the revolution in 1978.

Moreover, long-term coefficients, the error correction model to examine how moderate, short-term imbalance offers long-term equilibrium. Check convergence and long-term relationship between the deficits has been used in the volume of liquidity and inflation period (1975-2006). Isotropic ARDL technique was used for the natural logarithm of variables. To estimate the statistical model time series data has been used from 1975 to 2006 for the Iranian economy. The first step is necessary to estimate the model. We examined the variables for the cointegration and the stationary relationship between the variables, and then estimated coefficients and long-term correction factor.

\section{Results and Discussion}

To establish the order of integration Dickey - Fuller generalized test is used. The results of Dickey-Fuller generalized level variables respectively marked $\mathrm{a}$ and $\mathrm{b}$ show has been presented in the following table.

Table 1: test results Dickey - Fuller generalized level variables

\begin{tabular}{llllcccc}
\hline \multicolumn{2}{c}{ Ln GDPR } & \multicolumn{2}{c}{ BDT } & \multicolumn{3}{c}{ Ln M2 } & \multicolumn{3}{c}{ Ln CPI97 } \\
\hline Critical & Statistics & Critical & Statistics & Critical & Statistics & Critical & Statistics \\
-2.95 & -1.25 & -2.94 & -4.29 & -2.94 & 1.01 & 2.94 & 1.21 \\
-3.55 & -2.25 & -3.53 & -4.48 & -3.35 & -1.85 & -3.35 & -2.23 \\
\hline
\end{tabular}

According to Table 1, all variables are stationary (except BDT variable) and BDT variable is nonstationary and that will be stationary with a time difference making. ARDL method includes two stages estimated coefficients for the long term. Firstly there long-term relationship predicted by economic theory examines the issue between the variables and if there is a long term relationship, the second stage is estimated coefficients of short term and long term model. Here for the long-term relationships we use error correction model as follows.

$$
\begin{aligned}
& \Delta L C P I 76=\alpha_{0}+\sum_{i=1}^{n} b_{i} \Delta L C P I 76_{t=1}+\sum_{i=1}^{n} c_{i} \Delta L M_{t-i}+\sum_{i=1}^{n} d_{i} B D T_{t-i}+\sum_{i=1}^{n} e_{I} L G D P R \\
& +\gamma_{1} L C P I 76_{t-1}+\gamma_{2} L M_{t-1}+\gamma_{3} B D T_{t-1}+\gamma_{4} L G D P R_{t-1}
\end{aligned}
$$

Computational statistics $\mathrm{F}$ is the amount equal to $\mathrm{F}$ (LCPI76 / LM, BDT, LGDPR) $=8.8387$. That is larger than the upper range of critical value in the five percent significant level 3.34. Consequently, zero hypothesis is rejected based on lack of long-term relationship. Here we can repeat the test with the dependent variable move for other states and is appeared to be the number of long-term relationships. Now that is approved to exist of long-term relationship, we estimate Eq. 1 using the ARDL (m, n, p, q) model. The results of this estimate are expressed in Table 2. 
Table 2: model estimation results ARDL $(1,0,0,1)$

\begin{tabular}{|c|c|c|}
\hline Variable & Coefficient & t-statistic \\
\hline LCPI76(-1) & 1.23 & $8.6542^{* *}[010]$ \\
\hline LCPI76(-2) & -2.24 & $-1.987 * *[020]$ \\
\hline LM & 0.189 & $3.654 * *[001]$ \\
\hline LGDPR & -0.191 & $-2.3673^{* *}[024]$ \\
\hline BDP & 0.028 & $0.564 *[324]$ \\
\hline $\operatorname{BDT}(-1)$ & 0.087 & $2.542 * *[001]$ \\
\hline D78 & 0.0492 & $-1.964 *[010]$ \\
\hline D94 & 0.31 & $4.721^{* *}[002]$ \\
\hline \multirow[t]{2}{*}{ ECM } & -0.34 & - 4.701[000] \\
\hline & $\mathrm{R}$-Squared $=0.99$ & DW-statistic $=2.05$ \\
\hline
\end{tabular}

Also Cumulative Sum and Cumulative Sum of Square tests have been done to check the stability of model coefficients and results are shown in graphs (a) and (b). Results show that the estimated model coefficients are stable in the period studied. It should be noted that in these graphs, straight lines express critical boundaries in five percent significance level.

\section{Fig.1. Plot of CUSUM and CUSUMQ statistics for coefficients Stability Tests}

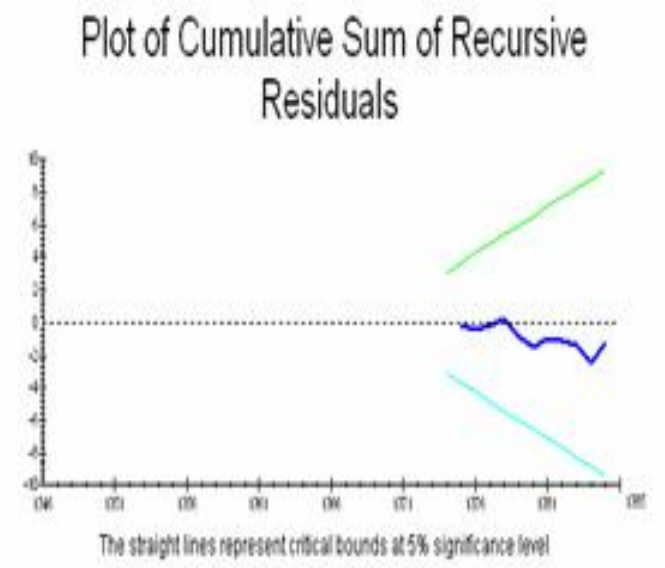

(a)

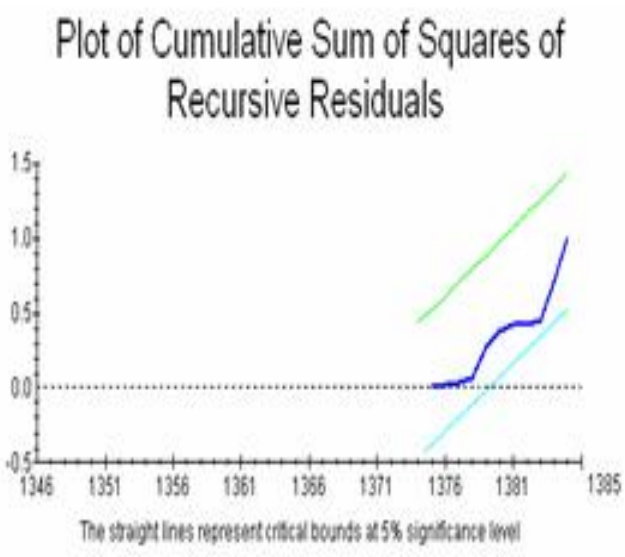

(b)

The existence of long-term equilibrium relationship in the first stage estimated coefficients can be longterm. If you can see in Table (3), coefficients of variables are in accordance with the principles of macroeconomic theory.

Table 3: Long-term coefficients based on ARDL model

\begin{tabular}{lcr}
\hline Regressor & Coefficient & T-Ratio (prob) \\
\hline LM & 0.964 & $12.325^{* *}[001]$ \\
LGDPR & -0.5421 & $-6.231^{* *}[010]$ \\
BDT & 1.821 & $2.418^{* *}[728]$ \\
D78 & -0.726 & $2.572^{* *}[009]$ \\
D94 & 0.436 & $2.994^{* *}[013]$ \\
\hline
\end{tabular}

Source: research findings *Significant in the level10\% ${ }^{* *}$ Non Significant at the level \%5

Time series data (1975-2006) is analyzed for non stationary and stationary using the Dickey - Fuller generalized test and show that the variables (except BDP variable) are non-stationary and they will be stationary with a time difference making. The relationship between the ratio of deficit to GDP and size monetary inflation is positive. But the impact of the deficit ratio to GDP is higher than the inflation impact of monetary volume. So that a percent change in the ratio of deficit to GDP inflation changes 1.82 percent. But a percentage change in logarithmic volume alter monetary inflation rate of 0.96 percent. Rate of real GDP is also marked as Theoretical negative. Dummy variables, the revolution (D78) has a negative 
influence and unification of exchange rates (D94) has a positive influence on inflation. Error Correction Model (ECM) in the ARDL test tells to exist of long-term relationship between variables and that is negative and large. its size was estimated to -0.34 and the expression that if we move from period $\mathrm{T}$ to period $\mathrm{T}+1$, SD government deficit is corrected by long-term path of the template variable rate -0.34 . This shows that if any shock or imbalance to be entered in the state budget deficit; we can get back into balance after a nearly three-year period, so the speed is adjusted up and be acceptable.

\section{Conclusion}

Generally, results indicate that the relationship between government budget deficit with money growth and inflation depends on way of creating the budget deficit, financing method and country's macroeconomic conditions. This paper has discussed the relationship between government budget deficit and inflation in Iran during the period 1975-2006 and concluded that the period 1975-2006 government budget deficit has no significant correlation with inflation in Iran while it is observed a significant positive relationship between inflation and money growth. In this paper based on material obtained if budget deficit change to one percent, the inflation rate will change to 1.82 percent. Of course, other factors such as much money influences on inflation. So the Central Bank of Iran (CBI) can't act independent monetary and inflationary policies. Consequently, any solution about disinflation should be accompanied by controlling and real reduction in the budget deficit. Therefore it is recommended that the best method of reducing government budget deficit is increasing incomes and reducing costs. Since in the economy of Iran power of absorbing money is limited, so there must be a balance between physical and human resources on one hand and currency and money on the other hand. Therefore government expenditure should be reduced to control the growth rate. It is recommended that studies may consider financing methods in different time intervals.

\section{References}

Aghevli, B. and Khan, m. (1977). Inflationary Finance and the Dynamics of Inflation: Indonesia, 19511972. American Economic Review, 67(3): 390-403.

Aghevli, B. \& khan, M. (1978). Government Deficit and Inflationary Process in Developing Countries. I.M.F Staff Paper, 25(3): 383-416.

Alavirad, A. (2006). The budget deficit and inflationary process in Iran, apply VAR method. Journal of Political and Economic Ettela'at, 20: 258-267.

Barro, R. (1974). Are Government Bonds Net Wealth? Journal of Political Economy, 82(6): 1095-1117.

Dickey, D., A. \& Fuller W., A. (1981). Likelihood ratio statistics for autoregressive time series with a unit root. Econometrica, 49 (4): 1057-72.

Favero, C., A. \& Spinelli, F. (1999). Deficits, money growth and inflation in Italy. 1875-1994, Economic Notes, 28(1): 43-71.

Francis, F., W. \& Miller, S., M. (1985). The relationship between government deficits, money growth and inflation. Journal of macroeconomics, 7(4): 447-467.

Jafari-Samimi, A. (1992). The Relationship Between Inflation and Budget Deficit in Iran, a theoretical \& Empirical Analysis. Islamic Azad University, Tehran, Iran.

Johansen, S. (1988). Statistical analysis of co integration vectors. Journal of Economic Dynamics and Control, 12(3): 231-54.

Mousavi-Azad A. (1999). Relationship between government budget deficit, economic growth and inflation in Iran. University of Tehran, Iran.

Protopapadakis, A. \& Siegel, J. (1987). Are money growth and inflation related to government deficit? Evidence from ten industrialized economies. Journal of International Money and Finance, 6: 31-48. 